\title{
Study of Commuting to Origin on the Weekend: Case study of Migrant Workers
}

\author{
${ }^{1}$ Andrei L. Vartanova \\ ${ }^{1}$ Faculty of Public Administration, Lomonosov Moscow State University, Moscow, 119991, Russian Federation. \\ 1andreivarta@outlookmail.com
}

\author{
Article Info \\ Journal of Journal of Enterprise and Business Intelligence (http://anapub.co.ke/journals/jebi/jebi.html) \\ Doi: https://doi.org/10.53759/5181/JEBI202101002 \\ Received 18 August 2020; Revised form 12 September 2020; Accepted 12 December 2020. \\ Available online 05 January 2021. \\ (C2021 Published by AnaPub Publications.
}

\begin{abstract}
This study aims to find out the determinants of formal sector migrant workers in Mamuju Regency commuting to their area of origin on weekends at least once in the last month when the survey was conducted. The data used in this study are primary data with a sample size of 200 respondents in several government and private agencies. Sampling is done by using purposive accidental sampling. The analysis technique used is the Binary Logistic Regression Analysis. The results showed that (1) out of 200 migrant workers in the formal sector surveyed in August-September 2017, there were 119 people (59.5\%) commuting. Among the 119 commuters, there were $13(10.92 \%)$ commuting weekly in the last month, and $54(45.39 \%)$ commuting once a month. (2) The factors of age, level of education, the status of residence in Mamuju, and the cost of living in Mamuju are stimulus factors making migrant workers decide to do the commuting to the migrant's home area, while other variables are not significant. (3) Another factor is the availability of inadequate real estate facilities and infrastructure, where the economic sector is not a base sector in Mamuju Regency so that it allows migrant workers to commute to their area of origin on weekends, especially for migrant workers coming from Makassar City and other regions that have more complete real estate facilities.
\end{abstract}

Keywords - Migrant Workers; Migration; Relation to Self Confidence; Effect on Sports Performance; Implications of the theory.

\section{INTRODUCTION}

Migration is one of the important issues and is widely studied in relation to population, labor, and economic problems in a region or country. One of the main concerns in labor migration is the migration of migrant workers from rural areas to urban areas (rural-urban migration) that occur in several developing and developed countries [1]. Large-scale labor migration to unmanageable urban areas has a greater negative impact than the positive impacts received in urban areas. Migrant workers who migrate commuting to cities pose a huge cost to the government in providing employment, providing transportation equipment, road infrastructure, energy, and public services [1].

Another impact of the high migration of residents to cities is the occurrence of excess demand over the supply of goods and services (supply limitations) pushes the price level of goods and services to increase. Likewise, wage rates for workers in cities will tend to increase along with the rate of urbanization in urban areas [2]. Based on the research results of Madris, et al. [3], that the Mamuju Regency in the city category is being seen in terms of population, having a share of the agricultural, forestry, and fisheries sector to the total GRDP from year to year decreasing, whereas the share of non-primary sectors is increasing, experiencing a second economic growth rate the highest was in West Sulawesi, which was 9.24 percent per year during the period 2010-2015. On the other hand, there are 14 sectors in the base sector category among the 17 sectors analyzed.

Some sectors that experienced growth rates above 10.00 percent, namely the government administration sector, defense, and social services, government health services and the social sector (16.24\%); waste, water, waste, and recycling management sector (15.85\%); electricity and gas procurement sector (12.41 50; information and communication sector $(11.19 \%)$; financial and insurance services $(11.12 \%)$; the provision of food and beverage accommodation (10.77\%); education sector $(10.20 \%)$, while other sectors are below 10.00 percent on average per year during 2010-2015. Associated with the results of the above research and empirical data, theoretically, it will have implications for the advancement of civilization in an area (social, economic, and cultural), which is marked by the increasing availability of facilities and infrastructure. Thus, the development of the Mamuju Regency as the Capital of the Province will have an impact on increasing attractiveness as a destination for migrants, both inter-district / city migration, provincial migration, and international migration. This indication is indicated by the high population growth rate, which is 3.60 percent above the natural population growth during 2010-2015. This shows that the population of migrants entering the city of Mamuju is relatively large. 
Labor, as a capital for the development of an area, shows that the number and composition of the workforce also continue to change along with the ongoing development and demographic processes. In 2015 in Mamuju Regency, there were 180,373 working-age populations aged 15 years and over with a Labor Force Participation Rate (TPAK) of 70.06 percent in 2015. Then, the portion of job seekers who were openly unemployed amounted to 4,776 people or 3, 78 percent of the total workforce. When viewed from the highest educational background that was completed, there were 42,984 residents who worked only with junior high school education and below [4].

In relation to the pattern of household consumption expenditure, it appears that the average consumption expenditure in urban areas is higher than in rural areas, which are respectively Rp744,948.00 and Rp443,263.00 in 2014. This shows that the costs of living in urban areas are almost twice greater than the cost of living in rural Mamuju District. While on the other hand, the pattern of household, food, and non-food consumption expenditure in Mamuju Regency, respectively between 52.76 percent and 47.24 percent, shows that the standard of living of the people in Mamuju Regency is still relatively low [5]. Pay attention the above; there appears that a contradiction between the pattern of household consumption expenditure and the high average household expenditure in urban areas, so there is an issue that lodging costs in Mamuju Regency, especially in Mamuju District, are relatively higher compared to lodging costs in the City Makassar or other districts in South Sulawesi.

The results of our interviews show the high cost of accommodation and the high level of expenditure for community consumption in Mamuju Subdistrict (Urban Area), enables the high tendency of formal sector workers to commute from workplaces in Mamuju City to the place of origin where their families live, both on weekends and every month for workers in the formal sector, where this condition can interfere with work productivity as a result of the cumulative activities on every weekend. The decision of workers commuting to Mamuju City is a migration phenomenon that has an important role in the development process that affects the distribution of population in an area or region, so it is deemed necessary to conduct a population economic study related to what factors cause workers in the formal sector to choose to do the most not once in the past month on every weekend from Mamuju City to his home address or family residence.

\section{RESEARCH OBJECTIVE}

This study aims to determine the determinants of migrant workers in the formal sector in the City of Mammuju, who come from outside the Mamuju regency to go to the area of origin at the weekend.

\section{Migration in conceptual review}

According to Tjiptoherijanto [6], migration is a permanent or semi-permanent migration of people based on territory and time [6]. Siegel and Swanson define migration as a demographic concept that encompasses population mobility referring to spatial, physical, or geographical movements which constitute population mobility across political or administrative boundaries of a village, sub-district, district, province, and even cross-border region [7]. Then Weeks [8] argues that someone who moves from one location to another but does not intend to stay is not called a migrant, but is referred to as a perpetrator of the shooting, even though the act actually illustrates mobility [8]. The Badan Pusat Statistik (BPS) defines migration as a movement of the population with the aim of settling beyond administrative boundaries (internal migration) or political boundaries of the country (international migration) for a minimum stay period of six months in a row. Migration can be grouped based on two important dimensions in migration analysis, namely the spatial/regional dimension and the time dimension. Thus, migration is the migration of people from one administrative region to another administrative area with the aim of residing or settling in a new place [9].

\section{Theoretical Review}

Becker [10] explains that migrating is a choice in which an individual will make rational decisions in determining the choice of several alternatives available in providing maximum benefits (maximum Utility) for himself in the migration process [10]. The information a person has about the benefits of migrating also plays an important role in migration decision making. If the benefits are higher than the costs of migrating, then it is likely that someone will decide to migrate. Susilowati [11] cites Speare, that in addition to economic motives labor migration is also influenced by noneconomic factors, for example, structural characteristics, socio-demographic characteristics, characteristics of the area of origin and destination, geographical conditions, and characteristics of social communities that influence decisions on places lives and influences the intention to migrate [11].

Elda and Racmanina [12] analyzed migration using the place utility model (stress-threshold model). This model explains that the movement of labor is based on individual decisions that are influenced by the fulfillment of needs and stresses (stress-threshold) in the area of origin [12]. Rational individual assessment of the conditions of residence and place of work is influenced by the characteristics of the individual, household, and neighborhood. This is in line with the opinion of Susilowati [11], which states that the condition of the area of origin that causes individuals to experience dissatisfaction in meeting their needs, provide3s stress pressure that affects an individual's decision to migrate [11]. 
The next development of migration theory, namely the theory of labor migration between two sectors (two sectors of surplus labor) formulated by Lewis which explains the movement of labor between two sectors, namely the traditional sector in the village towards the existing modern industrial sector in urban areas. Thus, workers will migrate from the sector with low productivity to the sector with high productivity [1]. Economic development will drive the structural transformation of the economy, changes in the structure of the economy shifting from the traditional agricultural sector to the modern industrial sector. Lewis assumes that there is a transfer of labor from the traditional sector (agriculture) that has a surplus of labor will be absorbed into the modern industrial sector in the city that requires labor due to the expansion of production in the modern sector [1]. It was further stated that the process of growth and expansion of output in the industrial sector would continue to increase employment and growth of employment opportunities in the industrial sector. Thus, it will cause the migration of workers who are concentrated in urban areas.

\section{Empirical Review}

Differences in real income are the main cause of labor migration. The difference in real income between the area of origin and that received by migrant workers in the city will have a positive effect on the decision to migrate. The higher the income received by migrant workers in the city, the greater the interest of migrant workers to migrate commuting to the city [1], [13]. However, it is different from the findings of some research, that wage differences between regions are narrowed by easy travel between the two regions, while some research found a loss of the negative effects of local wages by external workers.

Different opinions expressed by Mare and Choy stated that labor migration is not influenced by the amount of income to be obtained, but is more influenced by facilities and infrastructure, living environment conditions, security and comfort of workplaces, and low unemployment rates are considered labor migration work [14]. Likewise, the findings of Jose Ignacio et al. stated that there is a complex relationship between forms of urban and commuting behavior [15]. Nashrul [16] further argues that income is not the main reason for workers to migrate, but the greater employment opportunity factor in the destination area is the main reason for migrating, because the greater the wage differentials, the opportunity to obtain employment opportunities is even smaller, while geographical differences in average wages and hence the tendency to look for better location matching, when the realization of income at the origin location is unprofitable [16]

Borjas argues that the decision to migrate migrant workers is dominated by workers who have a high educational background [17]. Higher education will encourage workers to commute to increase opportunities for employment and higher income in urban areas. This is in line with Joan Llull, which states that local residents will try to improve education as a result of the arrival of migrants with higher levels of education [18]. Yang \& Guo argue that there is a relationship between the level of education the workforce has and the decision to migrate [19]. Highly educated workers have a higher probability of migrating commuting compared to workers with low education. Mitchell explains that marital status will influence the decision to migrate workers. Marital status is a family factor that influences the decision to migrate workers. Marital status is a force that binds someone to migrate commuting. So unmarried workers have a higher probability of the tendency to migrate commuting compared to married workers [20]. Different opinions expressed by Nurwati and Setiawan argue that married workers are considered to be more migratory than unmarried workers [21]. According to Bodvarsson and Berg argues that family factors are the main factors that are considered for workers to migrate because workers have family member dependents, and this finding is reinforced by the findings of Guoliang Li et al. that family factors have a weak influence to return to the page [22], [23].

Saefullah describes the types of modern jobs in the city that attract migrant workers as professionals to work in the formal sector and settle in the city [24]. Types of jobs in the city require professional workers who have certain skills and expertise with a high level of education for professionals who have specific expertise (specialization) who work in formal employment. Kenney argues that a professional workforce has innovation, expertise, and highly educated so as to provide higher work productivity compared to unprofessional workers [12]. Thus, professional workers have a higher tendency to migrate commuting compared to unprofessional workers. In line with the findings of Farid $\mathrm{F}$ and David $\mathbf{J}$ that workers with low skills in the city get more benefits from the condition of city congestion and the existence of agglomeration [25].

Nurwati and Setiawan explained that the migration of workers based on employment status in the formal sector is permanent to settle. Migrant workers who work in the formal sector have skills and higher education [25]. Employment status in the formal sector attracts migrant workers to work that provides high wages, employee guarantees and benefits, and rules for employee protection by the government that are better than the informal sector. Migrant workers who work in the informal sector will choose not to settle in the destination area because open access makes it easy to move, not bound in choosing work. Workers in developing countries are interested in carrying out internal and international migration only at short distances, aiming to large cities based on industrialization. Consistent with the previous opinion, Ehrenberg and Smith [26] explain that migrant workers are more interested in migrating short distances than long distances because it makes it easy to obtain information in measuring the magnitude of the opportunity that is gained 
will be greater if working near from their home region. The information obtained about distance is a proxy of the number of physical costs incurred in migration [26].

\section{RESEARCH METHODS}

\section{Research time and location}

This research was conducted in Mammuju Regency, West Sulawesi Province, from August to December 2017.

\section{Research design}

This research is a form of survey research that aims to describe the relationship between one variable with another variable (explanatory research). Before conducting a survey (primary data), secondary data retrieval is very important to know the general description of the area and the object of research, including social, economic, and cultural phenomena in the study area. Primary data collection was carried out through surveys using a structured questionnaire (questionnaire) and also conducted interviews directly with respondents to obtain more in-depth information (in-depth interview). The population in this study are civil servants and private employees who work in Mamuju City who come from outside Mamuju City who have a family (marital status), both those who live with their families in Mamuju City and whose families live outside Mamuju City shooting on every weekend. Then the unit of analysis in this study is the household.

\section{Sampling method}

Based on the above population, a proportional sample of civil servants and private employees are determined. Determination of respondents is done in a cluster based on the agency or institution where the respondent works and is stratified based on the hierarchy of positions and length of stay in Mamuju City. Based on the agency or institution chosen as the respondent's place of work, then the sample was chosen by accidental sampling method with a total sample of 200 households as the unit of analysis. This method is used with consideration of relatively homogeneous population characteristics based on each of the existing household characteristics. Statistically, for cross-section data samples above, 30 units are considered to be appropriate to represent the population. The main criteria to be considered in the selection of samples (respondents) refer to the characteristics of the population and the analysis unit of the study. Interviews were conducted at the respondent's office during recess, at the respondent's home (Mamuju City), and when the respondent was doing the commuting at the terminal or on the bus.

\section{Analysis method}

To find out the factors of migrant workers commuting, a Binary Logistic Regression Analysis is used. This model was chosen because the affected variable (response variable) is categorized as a scale (dummy variable); that is, if the status of the respondent commuting is given a value $=1$, while respondents who do not commute are given a value $=0$. While the independent variable used to predict the response variable $(\mathrm{Y})$, is:

- The age of the migrant worker (X1) is measured at the time the survey is conducted (Year).

- Gender (dummy variable, X2), i.e. male migrant worker $=1$, and others $=0$.

- A number of RT members (X3), i.e., the number of people economically covered by the family in one household (Soul).

- Level of formal education (dummy variable, X4), i.e., Bachelor degree (Strata 1 and 2) =1; and another high school down $=0$.

- Type of work (dummy variable, X5), i.e. PNS / TNI / Polri = 1; and Public and Private Employees $=0$.

- Length of work (x6), measured by years of service as civil servant/military/police, and public/private employees (years).

- The length of stay in Mamuju (X7) is measured at the time of the survey (Year).

- Marital status (dummy variable, $\mathrm{X} 8$ ), which is temporary in marital ties $=1$; and others $=0$.

- Status of residence in Mamuju (dummy variable, X9), i.e. not rented $=1$; and rent $=0$.

- Cost of Living in Mamuju (X10), i.e., daily consumption expenses, local transportation, and others outside the cost of commuting, lodging costs in Mamuju City, and household costs in the area where the family lives for respondents who do not live together with his family in Mamuju (in thousands of rupiah per month).

- Total household income (X11), i.e., fixed income and non-permanent income for all migrant worker household members (in thousands of rupiah per month). 
Based on the categorization of the variables above, the binary logistic regression model is formulated as follows:

$$
\begin{aligned}
Y= & f(X 1, X 2, X 3, X 4, X 5, X 6, X 7, X 8, X 9, X 10, X 11, X 12, X 13) \\
Y= & \beta_{0}+\beta_{1} X_{1}+\beta_{2} X_{2}+\beta_{3} X_{3}+\beta_{4} X_{4}+\beta_{5} X_{5}+\beta_{6} X_{6}+\beta_{7} X_{7}+\beta_{8} X_{8}+\beta_{9} X_{9}+ \\
& \beta_{10} X_{10}+\beta_{11} X_{11}+\varepsilon .
\end{aligned}
$$

Where:

$$
\beta_{0}=\text { intercept }
$$

$$
\beta_{1} \text { To } \beta_{11}=\text { Regression Coefficient }
$$$$
\varepsilon \quad=\text { error term. }
$$

Dependent Variable Y follows Bernoulli's distribution with the function:

$$
\mathrm{f}(\mathrm{yi})=\pi(\mathrm{x})^{\mathrm{yi}}[1-\pi(\mathrm{x})]^{1-\mathrm{yi}} ; \mathrm{i}=1,2, \ldots ., \mathrm{n}
$$

The logistic regression probability model with the $\mathrm{p}$ factor (explanatory variable) is:

$$
\mathrm{p}=\frac{\exp \left(\beta_{0}+\beta_{1} \mathrm{x}_{1}+\ldots \ldots \ldots \ldots+\beta_{\mathrm{i}} \mathrm{x}_{\mathrm{i}}\right)}{1+\exp \left(\beta_{0}+\beta_{1} \mathrm{x}_{1}+\ldots \ldots \ldots \ldots+\beta_{\mathrm{i}} \mathrm{x}_{\mathrm{i}}\right)}
$$

$\mathrm{p}$ is the chance of commuting ie $\mathrm{Y}=1$ with a probability value of $0<\mathrm{p}<1$, and $\beta \mathrm{i}$ is a parameter value with $\mathrm{i}=1,2, \ldots$. , n.

The $\mathrm{p}$ function is a non-linear function, so logit transformation is needed to obtain a linear function so that the relationship between the response variable and explanatory variables can be seen.

By doing a logit transformation of $\mathrm{p}$, a simpler equation is obtained:

$$
\mathrm{g}(\mathrm{x})=\operatorname{In}[\pi(\mathrm{x}) /\{1-\pi(\mathrm{x})\}]=\mathrm{P}_{\mathrm{o}}+\mathrm{P}, \mathrm{x},+\ldots \ldots \ldots+\mathrm{P}_{\mathrm{p}} \mathrm{X}_{\mathrm{P}}
$$

In such a way that the logit transformation model becomes:

$$
\mathrm{g}(\mathrm{X})=\beta_{0}+\beta_{1} \mathrm{X}_{1}+\ldots \ldots \ldots+\sum \sum \beta_{\mathrm{u}} \mathrm{X}_{\mathrm{ju}}+\beta_{\mathrm{k}} \mathrm{X}_{\mathrm{k}}
$$

And the model that shows the opportunity (risk) of a household to be poor based on characteristics is:

$$
p=\frac{\exp \left(\beta_{0}+\beta_{1} X_{1}+\beta_{2} D_{1}+\beta_{3} D_{2} \ldots \ldots \ldots+\beta_{8} D_{7}\right)}{1+\exp \left(\beta_{0}+\beta_{1} X_{1}+\beta_{2} D_{1}+\beta_{3} D_{2} \ldots \ldots \ldots+\beta_{8} D_{7}\right)}
$$

Then transformed into a logit model, it becomes:

$$
P=\exp \left(\beta_{0}+\beta_{1} X_{1}+\beta_{2} D_{1}+\beta_{3} D_{2} \ldots \ldots \ldots+\beta_{8} D_{7}\right)
$$

Odds Ratio or Tendency Ratio

The usual odds ratio denoted by $\theta$ is defined as the ratio of Odds for dummy $=1$ to dummy $=0$. This odds ratio states the level of risk of the effect of observation with dummy $=1$, how many times compared to dummy observation $=0$.

Then the ratio odds are:

$\theta=$

$$
\left[\exp \left(\beta_{0}+\beta_{\mathrm{j}}\right) /\left\{1+\exp \left(\beta_{0}+\beta_{\mathrm{j}}\right)\right\} /=\exp \left(\beta_{0}+\beta=\exp \left(\beta_{\mathrm{j}}\right) 1 /\left\{1+\exp \left(\beta_{0}\right)\right]\right.\right.
$$

$$
\left[\exp \left(\beta_{0}\right) /\left\{1+\exp \left(\beta_{0}\right)\right\} / 1 /\left\{1+\exp \left(\beta_{0}+\beta_{\mathrm{j}}\right)\right\} \exp \left(\beta_{0}\right)\right.
$$




\section{RESEARCH RESULT}

The population of the Mamuju Regency in 2015 was 265,800 people consisting of 135,294 men and 130,506 women, and there were around 59,346 households with an average number of household members of around 4.5 people. In the same year, the population density of the Mamuju Regency reached 53 people per km2. The district with the highest population density is Mamuju District, with a density of 319 inhabitants per $\mathrm{km}^{2}$. In 2015 in Mamuju Regency, there were 180,373 working-age population, aged 15 years and over. Most of the working-age population who are active in economic activities are the labor force or the working-age population offering services to the labor market with a Labor Force Participation Rate (TPAK) in Mamuju Regency at 70.06 percent in 2015 [4]. On the other hand, the Open Unemployment Rate in 2015 was 3.78 percent - the development of TPAK and TPT in the Mamuju Regency. The number of people who have worked as of last week in 2015 (TPT) reached 121,587 people or 96.22 percent of the total workforce. (BPS, DDA Mamuju Regency, 2016). Of the 17 sectors, there are 14 economic sectors, which are the base sector in Mamuju Regency, but the real estate sector in Kabupaten Mamuju as the Capital of West Sulawesi Province does not appear to be a base sector or a superior sector. As the provincial capital, this sector should be superior to other sectors as a buffer for the flow of people shopping to other areas [3].

In connection with the results of the survey data analysis (2017) conducted, it appears that out of 200 migrant workers in the formal sector surveyed in Mamuju District, there were 119 people (59.5\%) commuting to their area of origin at least once in the past month during the survey was conducted, the remaining 81 people (40.5\%) did not do the shooting. Of the 119 commuters, there were 13 people $(10.92 \%)$ had been commuting every week in the past month, and 54 people (45.39\%) were commuting once every month. Among the 11 (eleven) independent variables that were hypothesized to be the determinants of commuting, there were 4 (four) variables (Table 1) that had a significant effect on the decision to do the weekend commuting for migrant workers, namely age, the status of the study, residence status in Mamuju, and the cost of living in Mamuju is at a significance level of 5 percent while the other 7 (seven) variables are not significant at the 10 percent significance level. Simultaneously the regression model appears valid, where the chi-square value of 176,882 with a significance value of 0.000 .

\section{Age Factor}

Based on the results of the logistic regression (Table 2), it appears that the effect of age on migrant (commuting) status is significant at the 1 percent significance level (sig. 0,000). A regression coefficient of 0.233 and an odds ratio or Exp (B) of 1.263 shows that the effect of age is positive, so the higher the age of migrant workers tends to be higher the possibility of commuting, which is 1,263 times higher than younger migrant workers. The results of this study contradict the results of Wahba's research [28], which took the case of workers in Makassar City who were commuting every day outside Makassar City (Gowa and Maros) after completing economic activities (working) in the afternoon or at night. Likewise, the results of the Haidir study, where the age factor did not significantly influence the decision of workers to commute migration in Mamuju Regency [27].

\section{Gender factor}

Statistical Test Results (Table 2). Shows that there is no difference in the tendency of commuting to the area of origin of migrant workers between men and women. This is indicated by the insignificance of the sex factor as a deciding factor in the decision to do the shooting at a significance level of 10 percent (sig. = 0.392). The results of this study are different from the results of the Haidir study, 2017, where men are more likely to be 5,262 times compared to women in computing [27]. Likewise, the research of Jose Ignacio, et al. [15] found that the ratio of men and women is inversely proportional to travel time in America. This difference is possible due to differences in the characteristics of the migrant population. Haidir [27] and Jose Ignacio, et al. [15] took the population both in the formal sector and in the informal sector, while in this study it took the case of migrant workers in the formal sector who were tight with formal working hours, especially for civil servants, the military, police, and BUMN employees, including in the banking and non-bank financial sector [27][15].

\section{Factor Number of Household Members}

The number of household members can be seen as a potential investment in the economic resources of a household, but on the other hand, it can also be a potential consumption that can increase individual satisfaction in a household, especially in the nuclear family. With more frequent homecoming or filming, more and more times consume household commodities (Z-googs) in the form of satisfaction gathering with family on weekends [10]. But related to the results of this study, the factor of the number of RT members did not become a determining factor in encouraging migrant workers to do the commuting to the area of origin at the weekend at least once in the past month. This is indicated by the insignificant influence of the number of household members on the migrant worker commuting status (sig. $=0.864)$ at a significance level of 10 percent (Table 1). Thus this study does not support the opinion of Bodvarsson and Berg [22] 
that family factors are the main factors that are considered for workers to do the shooting because workers have dependents of family members in the area of origin [22].

\section{Formal Education Factors}

Theoretically, Ehrenberg and Smith [26] have illustrated through graphs the relationship of education to annual earnings (annual earnings) [26]. Then Becker [10] defines that human capital from knowledge possessed by a person will encourage work productivity and, in turn, will receive compensation (income), which is assumed to be equal to the value of marginal productivity (VMPPl). Income retention will encourage the ability to purchase goods and services, including transportation services for weekend commuting by migrant workers [26]. However, it appears in table 1 that the results of this study do not support the theory of human capital, where formal education is not significantly related to the tendency of migrant workers to do the weekend commuting at a significance level of 10 percent.

Table 1. Results of Estimates of Determinants of Migrant Decision-Making Commuting To the area of origin on weekends

\begin{tabular}{|c|c|c|c|c|c|c|}
\hline \multirow[t]{2}{*}{ Determining Factors } & \multicolumn{4}{|c|}{ Statistical Value } & \multirow[b]{2}{*}{ Sig. } & \multirow[b]{2}{*}{$\operatorname{Exp}(B)$} \\
\hline & B & S.E. & Wald & Df & & \\
\hline Age (X1) & 0.233 & 0,058 & 16,136 & 1 & 0,000 & 1,263 \\
\hline Gender (X2) & 0.744 & 0,869 & 0,732 & 1 & 0,392 & 2,104 \\
\hline $\begin{array}{l}\text { Number of Household } \\
\text { Members (x3) }\end{array}$ & -0.070 & 0,408 & 0,029 & 1 & 0,864 & 0,933 \\
\hline Education (X4) & 4.303 & 1,109 & 15,068 & 1 & 0,000 & 73,950 \\
\hline Job Types (X5) & -1.065 & 1,030 & 1,069 & 1 & 0,301 & 0,345 \\
\hline Job Times (x6) & -0.613 & 0,645 & 0,905 & 1 & 0,341 & 0,541 \\
\hline $\begin{array}{l}\text { Dwelling Time in Mamuju } \\
\text { (X7) }\end{array}$ & 0.638 & 0,624 & 1,046 & 1 & 0,306 & 1,894 \\
\hline Marriage (X8) & 0,965 & 0,910 & 1,124 & 1 & 0,289 & 2,626 \\
\hline $\begin{array}{l}\text { Dwelling Statue in Mamuju } \\
\text { (X9) }\end{array}$ & $-7,112$ & 1,338 & 28,254 & 1 & 0,000 & 0,001 \\
\hline Living Cost in Mamuju (X10) & 0,000 & 0,000 & 16,692 & 1 & 0,000 & 1,000 \\
\hline Total Income RT (X11) & 0,000 & 0,000 & 0,640 & 1 & 0,424 & 1,000 \\
\hline Constant & $-0,181$ & 1,548 & 0,014 & 1 & 0,907 & 0,835 \\
\hline
\end{tabular}

Dependent Variable Y (Dummy); Y=1 (Commuting); $\mathrm{Y}=0$ (another).

Table 2. Omnibus Tests of Model Coefficient

\begin{tabular}{llccr}
\hline & & & & \multicolumn{2}{c}{ Sig. } \\
\hline Step 1 & Step & 176,882 & 11 & 0,000 \\
& Block & 176,882 & 11 & 0,000 \\
& Model & 176,882 & 11 & 0,000 \\
\hline
\end{tabular}

This shows that the tendency of migrant workers with higher education is relatively similar to migrant workers who have graduated from high school and below. So formal education completed is not a stimulus factor for migrant workers commuting to their area of origin on weekends. The results of this study turn back to the results of the research of Borjas 
[17] and Yang \& Guo [19], which states that there is a relationship between the level of education owned by the workforce and the decision to migrate [17], [19]. Highly educated workers have a higher level of probability to migrate commuting compared to workers with low education, as some research shows that migration inflows encourage the restructuring of production.

\section{Job Type Factors}

The types of work are divided into two categories, namely groups (PNS, TNI, and Polri) and other groups. Based on the results of logistic regression analysis, it appears that there is no difference in the tendency of migrant workers based on employment status. This is indicated by the Wald statistical test $=1.069$ and sig. $(\mathrm{P})=0.301$ greater than the significance level used $10 \%(\mathrm{p}=0.10)$. The results of this study reinforce the results of Wahba's research [28] in which workers who do daily commuting from the area of origin to the city of Makassar do not correlate significantly with the type of work he is engaged in [28]. However, in contrast to the results of research by Joan Llull [18] and Elda and Rahmanina [12], who found that the professional workforce has innovation, expertise, and highly educated so as to provide higher work productivity compared to unprofessional workers. Thus, professional workers have a higher tendency to migrate commuting compared to unprofessional workers [12], [18]. Ehrenberg and Smith [26], those migrant workers are more interested in migrating short distances than long distances, and the main destination is industrialized-based cities because it makes it easy to obtain information and all urban facilities that are available [26].

\section{Length of Work Factor}

The length of work is the number of years of work in the formal sector (last job) at the time the survey was conducted. Length of work or work experience is part of human capital, in addition to education, health, and migration. It appears in table 1 that the factor of work time or work experience does not have a significant impact on the decision of migrant workers to commute or not commute to the area of origin on weekends at least once in the past month, where sig. $(\mathrm{P})=$ 0.341 more greater than the significance level used $\mathrm{p}=0.10$. This shows that the behavior of work duration variables is consistent with education variables, both of which are indicators of human capital, which are also not significant to the behavior of weekend commuting for migrant workers in Mamuju District (Table 1).

\section{Length of Stay in Mamuju}

The characteristics of migrant workers related to the length of stay in Mamuju do not have a significant effect on the decision to do the weekend commuting to the area of origin (Table 1). It may be that migrant worker actually hasn't or don't feel bored living in Mamuju. Thus, this study concludes that not because of boredom or boredom living in Mamuju is the reason why migrant workers tend to do weekend commuting to the migrant's home area.

\section{Marital Status Factors}

Related to marital status, some previous studies such as Mitchell explained that marital status would influence the decision to migrate workers. Marital status is a family factor that influences the decision to migrate workers [20]. Marital status is a force that binds someone to migrate commuting because they do not want to be separated from their families. So unmarried workers have a higher probability of the tendency to migrate commuting compared to married workers. Meanwhile, Carta and De Philippis [29] stated that marital status has an influence in making decisions in the number of commuting [29]. Different opinions expressed by Nurwati and Setiawan [21] argue that married workers are considered to be more migratory than unmarried workers [21]. Bodvarsson and Berg [22] argue that family factors are the main factors that are considered for workers to migrate because workers have dependents on family members in the area of origin [22]. However, Wahba [28] found that marital status was not a determining factor for migrant workers in Makassar City commuting daily to the origin areas of Gowa Regency and or Maros Regency [28]. Then this study reinforces Wahba's [28] findings that the marital status factor is not a determining factor for the number of migrant workers in Mamuju City who have decided to do their homestay at least once in the past month [28] (Table 1).

\section{Status of Residence in Mamuju}

Status of residence is distinguished between rented houses and others as a comparison. This variable is significant at the $5 \%$ significance level, namely with a value of sig. $(\mathrm{P}=0,000)$ and with an odd-ratio (Exp $\mathrm{B}=0.001)$. This means that migrant workers who rent a house are 0.001 times compared to migrant workers who do not contract a house commuting to their area of origin on weekends, at a ratio of 1: 100 (Table 1). So, the absolute ratio of frequencies of commuting between contraception and non-contractor is 1: 100; in other words, migrant workers who do not have a home contract are 100 times more likely to do the shooting than those who are not contracted. It may be that those who are not in contact, have their own home, or have an official home, or live with their families, or because they have enough income because they do not have to pay rented fees every month so that they do their commuting on weekends. At the same time, those who rent a house feel the loss if the rented house is always left outside Mamuju Regency. 


\section{Living Cost Factors}

The variable cost of living total household consumption expenses and other living costs beyond the cost of housing a contractor for those who contract and the cost of commuting for those commuting. The cost of the living variable (Table 1) seems significant at the $1 \%$ significance level and sig value $(p=0,000)$. Nonetheless, the cost of living factor indicates that the likelihood of commuting on weekends is the same between migrant workers who have high living expenses and those who have relatively low living expenses, which are 1: 1 (have the same tendency).

\section{Total household income}

Speare and Harris [13] and Todaro [1] found that the higher the income received by migrant workers in the city, the greater the interest of migrant workers to migrate commuting to the city [1], [13]. However, Maré and Choy [14] differed in opinion; they stated that labor migration was not influenced by the amount of income to be obtained, but was more influenced by facilities and infrastructure, living environment conditions, security and comfort of the workplace into consideration of labor migration [14]. In another study, Haidir [27] found that income had a positive and significant effect on the decisions of formal and informal workers commuting to their area of origin [27]. However, it is different from Wahba [28] that the income factor does not have a significant influence on the decision of migrant workers in Makassar City to commute (roundtrip migration) in the afternoon and evening to migrant origin areas, namely Gowa Regency and Maros Regency [28].

The results of this study differ from the results of the Haidir study [27], but support the results of Wahba's research [28] in which total household income is not a deciding factor in the decision of migrant workers in Mamuju Regency to do their weekend commuting at least once in the past month [27], [28]. This indication is shown by the results of the binary logistic regression analysis model in Table 1 , where sig. $(\mathrm{p}=0.424)$ is greater than the significance level used, which is 10 percent. One reason why the income factor is insignificant is the population of this study is migrant workers in the formal sector (civil servants, military, police, and employees of state and private companies) who, on average, have relatively high income and are less varied. In contrast to the Haidir research [27], taking a sample of the population of migrant workers who work in the formal and informal sectors have a fairly varied level of income, ranging from lowincome groups to high-income groups [27].

\section{CONCLUSION}

The 200 migrant workers in the formal sector surveyed in Mamuju District, there were 119 people (59.5\%) commuting to their area of origin at least once in the last month when the survey was conducted. Among the 119 people who did the filming, there were 13 people $(10.92 \%)$ who were doing the weekly every week in the last month, and 54 people $(45.39 \%)$ did the once-monthly shooting. Age, education level, residence status in Mamuju, and the cost of living in Mamuju are stimulus factors that make migrant workers decide to do the commuting to the migrant's home area at least once a week in the last month. Other stimulus factors, such as gender, number of household members, type of work, length of work, length of stay in Mamuju, marital status, and total household income are not stimulus factors that must be considered in relation to migrant workers deciding to do the commuting to the area of origin of migrants on weekends at least once in the last month. Another factor that allows migrant workers to commute to their area of origin on weekends is the inadequate availability of real estate facilities and infrastructure, where the economic sector is not a base sector in Mamuju Regency, especially migrant workers coming from Makassar City or Parepare City who have more complete real estate facilities. The high flow of migrant workers' commuting in Mamuju Regency to the area of origin every weekend gives an indication that Mamuju as the Capital of West Sulawesi Province has not been sufficient in providing public facilities and infrastructures, and entertainment so that it will have an impact on the flow of money circulating outside Mamuju Regency following the flow migrant worker commuting. For this reason, the status of the Mamuju Regency to become the City of Mamuju should be realized as soon as possible. For researchers who wish to explore migration issues related to economic issues, it is recommended to examine the impact of remittances on migrant household economies; and the impact of the mobility flow of migrants on the money flow in the Mamuju Regency.

\section{References}

[1]. B. Marianna, N. Paolo, and V. Claudia, Urban Wage Premia, Cost of Living, and Collective Bargaining. WorkINPS Paper, 2018.

[2]. P. Tjiptoherijanto, "Population Mobility and Economic Development," in Symposium of the Office of the Minister of State for Transmigration and Population, 2000.

[3]. J. S. Siegel and D. A. Swanson, Method and Material of Demography, 2nd editio. USA: Elsevier Academic Press, 2004.

[4]. J. R. Weeks, Population: An Introduction to Concepts and Issues, 9th editio. Belmont: Wadsworth, 2004.

[5]. M. Rabbani and M. Dolatkhah, "Integration of Demand-Side Management Programs and Supply-Side Alternatives for Decentralized Energy Planning," International Journal of Applied Industrial Engineering, vol. 3, no. 1, pp. 37-54, Jan.

[6]. G. R. Wagner, “3 Export,” Schnelleinstieg Zoll für Import and Export - inkl. Arbeitshilfen online, pp. 35-58, 2018.

[7]. L. L. Bergeson, "The EPA Proposes Changes to RCRA Hazardous Waste Export and Import Regulations," Environmental Quality Management, vol. 25, no. 3, pp. 107-109, Mar. 2016. 
[8]. C. T. Thuy, "Vietnam-Asean Trade: Solutions for Vietnam's Import and Export," International Journal of Current Science Research and Review, vol. 04, no. 05, May 2021.

[9]. Y. Ogura, "Policy as a 'porter' of RE component export or import? Evidence from PV/wind energy in OECD and BRICS," Energy Economics, vol. 86, p. 104630, Feb. 2020

[10]. M. Rabbani and M. Dolatkhah, "Integration of Demand-Side Management Programs and Supply-Side Alternatives for Decentralized Energy Planning," International Journal of Applied Industrial Engineering, vol. 3, no. 1, pp. 37-54, Jan. 2016.

[11]. M. Gutierrez Soto and H. Adeli, "Many-objective control optimization of high-rise building structures using replicator dynamics and neural dynamics model," Structural and Multidisciplinary Optimization, vol. 56, no. 6, pp. 1521-1537, Oct. 2017.

[12]. S. Susilowati, "Impact of Labor Mobility on Rural Household Income," E-Journal Akunt., 2008.

[13]. L. P. Elda and L. Racmanina, "Do They Look for Informal Jobs ?: Migration of the Working Age in Indonesia," in 27th IUSSP International Population Conference, 2013.

[14]. J. A. Speare and J. Harris, “Education, Earnings, and Migration in Indonesia," Econ. Dev. Cult. Change, vol. 34, no. $20,1986$.

[15]. D. C. Maré and W. K. Choy, "Regional Labour Market Adjustmentand the Movements of People: A Review.," Treas. Work. Pap., 2008.

[16]. J. Ignacio, A. M. José, and V. Jorge, "The Commuting Behavior of Workers in The United States: Differences Between the Employed and The Self-Employed,” J. Transp. Geogr., vol. 66, pp. 19-29, 2018.

[17]. W. M. Nashrul, "Inter-Island Migration in Indonesia: an Analysis of The Migration Schedule Model and The Hybrid Gravity Model," Universitas Indonesia, 2010.

[18]. G. J. Borjas, "Economics of Migration," in International Encyclopedia of Social and Behavioral Sciences, 2000, vol. 3.

[19]. L. Joan, "Immigration, Wages, and Education: A Labor Market Equilibrium Structural Model," Rev. Econ. Stud., vol. 1, pp. 1-46, 2017.

[20]. Yang and Guo, "Occupational attainments of rural to urban temporary economic migrants in China 1985-1999," Int. Migr. Rev., vol. 30, pp. 771-787, 1996.

[21]. I. B. Mantra, "Mobility of Circular Population from Village to City in Indonesia," Yogyakarta, 1992.

[22]. Nurwati and Setiawan, "The Structure of Migrant and Non-Migrant Workers in the Suburbs of Bandung: A Potential for Conflict?," J. Kependud., vol. 1, no. 1, pp. 49-53, 2005.

[23]. O. B. Bodvarsson and V. D. Berg, The Economics of Immigration: Theory and Policy. New York: Springer Science and Business Media, 2013.

[24]. G. Li, F. Yanran, S. Yifan, C. Jingqiu, and M. Wang, "Effects of Family Encouragement on Migrant Workers' Return-to-Hometown Intention and Turnover: The Moderating Role of Career-Related Concerns," Career Dev. Int., vol. 25, no. 2, 2019.

[25]. A. D. Saefullah, "Non-permanent Internal Mobility in Population Mobility in Indonesia, Office of the Minister for Population / BKKBN and Demographic Institutions," Universitas Hasanuddin, 1996.

[26]. F. Farrokhi and D. Jinkins, "Wage Inequality and The Location of Cities," J. Urban Econ., vol. 111, no. C, pp. 76-92, 2009.

[27]. R. G. Ehrenberg and R. S. Smith, Modern labor economics : theory and public policy, Eleventh E. Britania Raya: Pearson Education, Inc., 2012. 